\title{
Penerapan Algoritma Artificial Neural Network untuk Klasifikasi Opini Publik Terhadap Covid-19
}

\author{
Euis Saraswati ${ }^{1}$, Yuyun Umaidah ${ }^{2}$, Apriade Voutama ${ }^{3}$ \\ 1,2,3 Teknik Informatika, Fakultas Ilmu Komputer, Universitas Singaperbangsa Karawang \\ E-mail: *1 euis.saraswati17028@ student.unsika.ac.id, \\ ²yuyun.umaidah@staff.unsika.ac.id, ${ }^{3}$ apriade.voutama@staff.unsika.ac.id
}

\begin{abstract}
Abstrak - Coronavirus disease (Covid-19) atau biasa disebut virus corona. Virus ini menyebar sangat cepat bahkan hampir menginfeksi seluruh dunia, termasuk Indonesia. Banyaknya jumlah kasus dan cepatnya penyebaran virus ini membuat masyarakat khawatir bahkan ketakutan akan penyebaran virus Covid-19 yang semakin meningkat. Informasi mengenai virus ini pun sudah tersebar diberbagai sosial media, salah satunya sosial media twitter. Berbagai opini masyarakat mengenai virus Covid-19 pun banyak dituangkan di twitter. Opini pada suatu tweet mengandung sentimen positif ataupun negatif. Kalimat sentimen yang terkandung dalam suatu tweet dapat dijadikan sebagai bahan pertimbangan dan evaluasi bagi pemerintah dalam menangani virus Covid-19. Berdasarkan permasalahan tersebut dibutuhkan klasifikasi analisis sentimen untuk mengetahui opini publik terhadap virus Covid-19. Penelitian ini menggunakan algoritma Artificial Neural Network (ANN) dengan metode Backpropagation. Hasil pengujian ini mendapatkan nilai accuracy $88,62 \%$, precision $91,5 \%$, dan recall 95,73\%. Hasil yang didapatkan menunjukkan model ANN cukup baik untuk pengklasifikasian text mining.
\end{abstract}

Kata Kunci - Covid-19, Opini Publik, Artificial Neural Network, Text Mining

\begin{abstract}
Coronavirus disease (Covid-19) or commonly called coronavirus. This virus spreads very quickly and even almost infects the whole world, including Indonesia. A large number of cases and the rapid spread of this virus make people worry and even fear the increasing spread of the Covid-19 virus. Information about this virus has also been spread on various social media, one of which is Twitter. Various public opinions regarding the Covid-19 virus are also widely expressed on Twitter. Opinions on a tweet contain positive or negative sentiments. Sentiments of sentiment contained in a tweet can be used as material for consideration and evaluation for the government in dealing with the Covid-19 virus. Based on these problems, a sentiment analysis classification is needed to find out public opinion on the Covid-19 virus. This research uses Artificial Neural Network (ANN) algorithm with the Backpropagation method. The results of this test get $88.62 \%$ accuracy, $91.5 \%$ precision, and $95.73 \%$ recall. The results obtained show that the ANN model is quite good for classifying text mining.
\end{abstract}

Keywords - Covid-19, Public Opinion, Artificial Neural Network, Text Mining

\section{PENDAHULUAN}

Awal tahun 2020, dunia dikejutkan oleh suatu wabah penyakit. World Health Organization (WHO) mengkonfirmasi bahwa penyakit ini bermula pada Desember 2019 yang berasal dari Wuhan, China [1]. Penyakit ini bernama Coronavirus disease (Covid-19) atau biasa disebut virus corona., Pada tanggal 2 Maret 2020 dilaporkan pertama kali Kasus Covid-19 di Indonesia. Dua warga Depok merupakan ibu dan anak terjangkit virus corona setelah berinteraksi dengan seorang warga negara asing asal Jepang [2].

Berdasarkan data yang diambil dari situs resmi Satuan Gugus Tugas Penanganan Covid-19 pemerintah Indonesia, terhitung sampai tanggal 7 Februari 2021 telah tercatat kasus aktif Covid-19 di Indonesia sebanyak 176.291 jiwa, sedangkan untuk korban meninggal dunia sudah mencapai 31.556 jiwa [3]. 


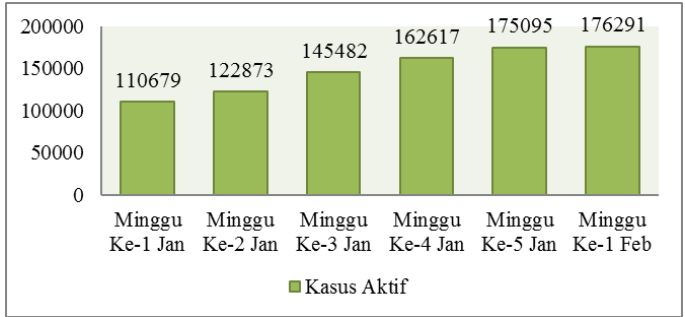

Gambar 1. Perkembangan Jumlah Kasus Aktif Covid-19 di Indonesia

Informasi mengenai virus ini pun sudah tersebar diberbagai sosial media, salah satunya sosial media twitter. Beberapa tahun terakhir, banyak sumber informasi yang dapat diperoleh melalui media sosial twitter [4]. Kelebihan dari twitter yaitu memiliki fitur trending topic terhadap isu yang sedang diperbincangkan di kalangan masyarakat. Berbagai opini masyarakat mengenai virus Covid-19 pun banyak dituangkan di twitter. Opini pada suatu tweet mengandung sentimen positif ataupun negatif. Kalimat sentimen yang terkandung dalam suatu tweet dapat dijadikan sebagai bahan pertimbangan dan evaluasi bagi pemerintah dalam menangani virus Covid-19. Selain itu, opini publik juga untuk menyelaraskan pendapat bagi masyarakat dalam menilai sebuah isu atau informasi. Berdasarkan permasalahan tersebut dibutuhkan klasifikasi analisis sentimen untuk mengetahui opini publik terhadap virus Covid-19.

Algoritma yang digunakan untuk melakukan klasifikasi analisis sentimen yaitu Artificial Neural Network (ANN). Kelebihan dari algoritma ANN dapat melakukan pelatihan berdasarkan data yang dipilih dan memiliki real time operation yang berarti dapat melakukan perhitungan secara paralel [5].

Penelitian sebelumnya yang menggunakan algortima ANN yaitu Ardika et al. (2020), mengenai Analisis Sentimen Data Pada BPJS Kesehatan Dengan Metode Backpropagation Neural Network, hasil yang didapatkan rata-rata precision sebesar $86.97 \%$, recall sebesar $87.14 \%$, dan accuracy sebesar 87,14\% [6]. Rohmawan (2018), mengenai Prediksi Kelulusan Mahasiswa Tepat Waktu Menggunakan Metode Desicion Tree dan Artificial Neural Network, hasil pengujian menunjukkan metode Artificial Neural Network memiliki akurasi lebih tinggi yaitu sebesar 79,74\% sedangkan Decision Tree memiliki akurasi sebesar 74,51\% [7]. Rozi et al. (2020), Analisis Mengenai Calon Presiden Indonesia 2019 di Twitter Menggunakan Metode Backpropagation, hasil klasifikasi yang didapatkan dari pengujian perbandingan data latih dan data uji memiliki nilai accuracy $90.6 \%$, nilai precision $90.8 \%$, nilai recall $84.2 \%$ [8].

Berdasarkan pembahasan yang telah diuraikan dan referensi dari penelitian sebelumnya, menunjukan bahwa Artificial Neural Network dapat digunakan untuk mengklasifikasikan suatu tweet dengan tingkat akurasi yang tinggi. Maka, penelitian ini juga akan menggunakan algoritma ANN untuk Klasifikasi Opini Publik Terhadap Covid-19. Evaluasi yang dilakukan dengan menghitung nilai accuracy, precision, dan recall menggunakan rumus confusion matrix. Manfaat dari hasil penelitian ini diharapkan dapat memberikan informasi yang benar mengenai virus Covid19 agar masyarakat tidak terpengaruh oleh berita hoax, serta untuk dijadikan bahan pertimbangan dan evaluasi bagi pemerintah dalam menangani Covid-19.

\section{2. .METODE PENELITIAN}

\subsection{Knowledge Discovery in Database (KDD)}

Knowledge Discovery in Database (KDD) adalah suatu cara untuk mendapatkan informasi dari sebuah database. Informasi yang diperoleh berupa basis pengetahuan (knowledge base) yang dapat digunakan untuk pengambilan keputusan [9].

\subsection{Artificial Neural Network}

Artificial Neural Network (ANN) merupakan suatu jaringan yang dibentuk berdasarkan jaringan saraf manusia. Sebuah sel saraf (neuron) terdiri dari fungsi penjumlah, fungsi aktivasi, dan 
keluaran. Neuron-neuron dalam neural network disusun suatu lapisan (layer), umumnya terdiri dari input layer, hidden layer, dan output layer [10].

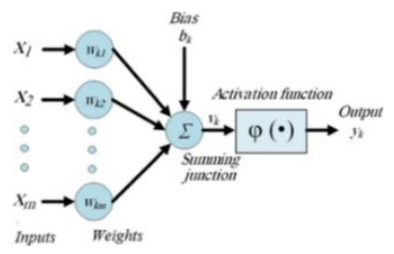

Gambar 2. Model Neuron

\subsection{Backpropagation}

Backpropagation adalah algoritma Artificial Neural Network bergerak dari output layer menuju input layer dengan menambahkan propagasi error. Metode backpropagation dapat mempercepat laju penggabungan, sehingga yang memiliki inputan data banyak dapat dilakukan dengan cepat [11].

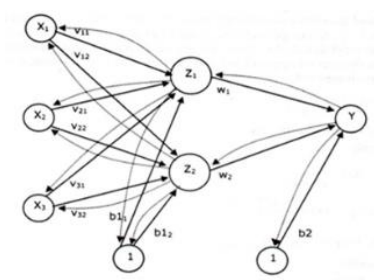

Gambar 3. Contoh Jaringan Backpropagation

Tahapan dalam pelatihan algoritma Backpropagation yaitu sebagai berikut [12]:

1. Inisialisasi bobot (atur bobot pada nilai acak yang kecil).

2. Tahap feed-fordward:

a. Setiap input layer $\left(\mathrm{X}_{\mathrm{i}, \mathrm{i}} \mathrm{i}=1,2,3, \ldots, \mathrm{n}\right)$ menerima sinyal masuk $\mathrm{X}_{\mathrm{i}}$ dan meneruskannya ke setiap hidden layer.

b. Setiap hidden layer $(\mathrm{Zj}, \mathrm{j}=1,2,3, \ldots, \mathrm{p})$ menjumlahkan bobot dari sinyal masuk dan ditambahkan dengan bias:

$$
Z_{i n j}=V_{0 j}+\sum_{i=1}^{n} X_{i} V_{i j}
$$

c. Kemudian kalikan hasil $Z_{\text {inj }}$ dengan fungsi aktivasi untuk menghasilkan output dari hidden layer dan mengirimkannya ke output layer:

$$
Z_{j}=f\left(Z_{i n j}\right)=\frac{1}{1+e^{-Z_{i n j}}} .
$$

d. Setiap output layer $\left(\mathrm{Y}_{\mathrm{k}}, \mathrm{k}=1,2,3, \ldots, \mathrm{m}\right)$ menjumlahkan bobot output dari hidden layer $\left(Z_{j}\right)$ :

$$
Y_{i n k}=W_{0 k}+\Sigma_{j=1}^{p} Z_{j} W_{j k}
$$

e. Kemudian kalikan hasil $Y_{\text {ink }}$ dengan fungsi aktivasi untuk menghasilkan output dari output layer:

3. Tahap backpropagation:

$$
Y_{k}=f\left(Y_{\text {ink }}\right)=\frac{1}{1+e^{-Y_{\text {ink }}}}
$$

a. Setiap unit output $\left(Y_{k}\right)$ akan menerima pola dari hasil training input, kemudian hitung nilai error dari output layer $\left(Y_{k}\right)$ :

$$
\begin{gathered}
\delta_{k}=\left(t_{k}-Y_{k}\right) f^{\prime}\left(Y_{i n k}\right) \ldots \\
\delta_{k}=\left(t_{k}-Y_{k}\right) Y_{k}\left(1-Y_{k}\right)
\end{gathered}
$$

b. Hitung koreksi bobot untuk merubah nilai $\mathrm{W}_{\mathrm{jk}}$ :

$$
\Delta W_{j k}=\alpha . \delta_{k} Z_{j}
$$


c. Hitung error pada unit tersembunyi $\left(\delta_{i n j}\right)$ :

$$
\delta_{i n j}=\sum_{k=1}^{m} \delta_{k} W_{j k}
$$

d. Kalikan $\delta_{\text {inj }}$ dengan turunan fungsi aktivasi dari input unit tersembunyi untuk menghitung nilai error:

$$
\begin{gathered}
\delta_{j}=\delta_{\text {inj }} f^{\prime}\left(Z_{\text {inj }}\right) \ldots \\
\delta_{j}=\left(\delta_{\text {inj }}\right) Z_{j}\left(1-Z_{j}\right)
\end{gathered}
$$

e. Hitung koreksi bobot untuk merubah nilai $\mathrm{V}_{\mathrm{ij}}$ :

$$
\Delta V_{i j}=\alpha \cdot \delta_{j} X_{i}
$$

4. Penyesuaian Bobot:

a. Setiap unit output $\left(\mathrm{Y}_{\mathrm{k}}\right)$ merubah bias dan bobotnya:

$$
W_{j k}(\text { baru })=W_{j k}(\operatorname{lama})+\Delta W_{j k}
$$

b. Setiap unit tersembunyi $\left(\mathrm{Z}_{\mathrm{j}}\right)$ merubah bias dan bobotnya:

$$
V_{i j}(\text { baru })=V_{i j}(\text { lama })+\Delta V_{i j}
$$

\subsection{Fungsi Aktivasi}

Fungsi aktivasi adalah output yang didapatkan pada sebuah neuron dengan menggunakan batasan aktivasi tertentu berdasarkan output dari penggabungan linier. Fungsi ini sebagai penentu nilai output dari suatu neuron [13].

Fungsi aktivasi sigmoid biner biasanya digunakan dalam ANN untuk pelatihan data dengan metode backpropagation. Fungsi aktivasi sigmoid biner memiliki range dari 0 sampai 1. Rumus fungsi aktivasi sigmoid biner [14]:

$$
\begin{gathered}
y=f(x)=\frac{1}{1+e^{-x}} \ldots \ldots \ldots \\
\text { dengan } f^{\prime}(x)=f(x)[1-f(x)]
\end{gathered}
$$

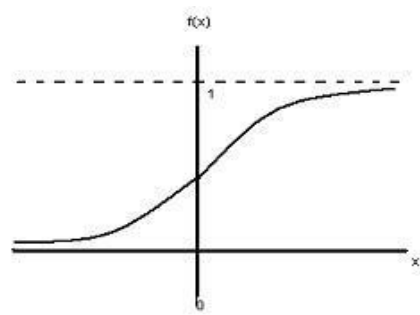

Gambar 4. Fungsi Aktivasi Sigmoid Biner

\subsection{Term Frequency-Inverse Document Frequency (TF-IDF)}

Term Frequency-Inverse Document Frequency (TF-IDF) adalah metode yang digunakan untuk menghitung bobotan setiap kata yang dihasilkan. TF adalah perhitungan jumlah kemunculan term dalam suatu dokumen, sedangkan IDF adalah perhitungan jumlah term umum yang muncul pada dokumen yang dianggap tidak penting [15].

\subsection{Confusion Matrix}

Confusion matrix adalah pengukuran kinerja hasil pengklasifikasian dalam mengenali baris data yang berbeda kelas. Saat pengkategori melakukan klasifikasi data yang bernilai benar akan memperoleh nilai True-Positive dan True-Negative, sedangkan data yang bernilai salah yaitu FalsePositive dan False-Negative [16]. 
Tabel 1. Confusion Matrix

\begin{tabular}{|c|c|c|c|}
\hline \multicolumn{2}{|c|}{ Data } & \multicolumn{2}{c|}{ Aktual } \\
\cline { 3 - 4 } \multicolumn{2}{|c|}{} & True & False \\
\hline \multirow{2}{*}{ Prediksi } & True & TP & FP \\
\cline { 2 - 4 } & False & FN & TN \\
\hline
\end{tabular}

Kinerja klasifikasi dapat dihitung menggunakan beberapa rumus. Hasilnya dapat berupa nilai accuracy, precision, dan recall yang biasa ditampilkan dalam persentase [17]. Rumus menghitung nilai kinerja classifier dapat dilihat pada tabel 2.

Tabel 2. Nilai Kinerja Classifier

\begin{tabular}{llc}
\hline \hline \multicolumn{1}{c}{ Nilai } & \multicolumn{1}{c}{ Penjelasan } & \multicolumn{1}{c}{ Rumus } \\
\hline Accuracy & $\begin{array}{l}\text { Persentase prediksi yang } \\
\text { berhasil atau bernilai benar }\end{array}$ & $\frac{T P+T N}{T P+F P+T N+F N}$ \\
\hline Precision Positif & $\begin{array}{l}\text { Persentase prediksi data positif } \\
\text { benar }\end{array}$ & $\frac{T P}{T P+F P}$ \\
\hline Precision Negatif & $\begin{array}{l}\text { Persentase prediksi data } \\
\text { negatif benar }\end{array}$ & $\frac{T N}{T N+F N}$ \\
\hline Recall Positif & $\begin{array}{l}\text { Persentase data positif yang } \\
\text { diprediksi sebagai positif }\end{array}$ & $\frac{T P}{T P+F N}$ \\
\hline Recall Negatif & $\begin{array}{l}\text { Persentase data negatif yang } \\
\text { diprediksi sebagai negatif }\end{array}$ & $\frac{T N}{T N+F P}$
\end{tabular}

\subsection{Metodologi Penelitian}

Metodologi penelitian yang digunakan yaitu Knowledge Discovery in Database (KDD). Tahapan KDD terdiri dari selection, preprocessing, transformation, data mining, dan interpretation/evaluation [18]. Berikut alur penelitian yang dilakukan.

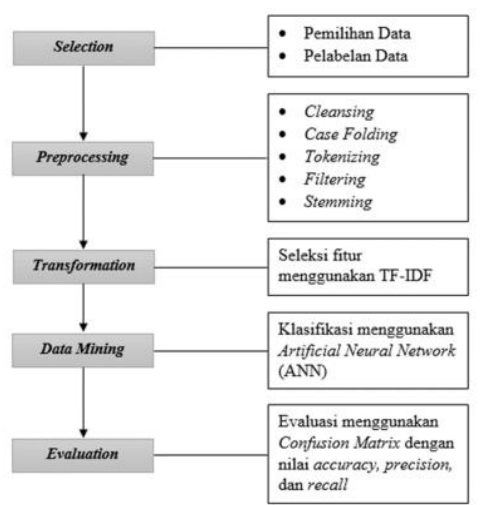

Gambar 5. Alur Penelitian

\subsubsection{Selection}

Dataset didapatkan dari hasil crawling yaitu proses pengambilan data dari twitter melalui API twitter, proses crawling menggunakan tools Rstudio. Proses crawling membutuhkan akun developer twitter, untuk pendaftarannya dilakukan di laman https://developer.twitter.com. Setelah mendaftar, developer akan mendapatkan consumer key, consumer access, access token dan access token secret. API Key dan API Secret Key digunakan untuk mengakses twitter menggunakan API. Access Token dan Access Token Secret digunakan untuk mengkoneksikan R dengan twitter.

Data yang telah diambil dari twitter dilakukan proses pelabelan kalimat positif dan negatif oleh ahli bahasa Indonesia untuk melanjutkan ke tahap prepocessing menggunakan RStudio. Penelitian ini memakai data time series yang didapatkan dari API twitter pada bulan April 2021. 


\subsection{2. $\quad$ Preprocessing}

Tahap preprocessing untuk melakukan pengurangan pada atribut yang kurang berpengaruh dalam proses klasifikasi. Preprocessing salah satu tahapan yang penting untuk dilakukan dalam proses KDD [19]. Beberapa tahapan preprocessing yaitu cleansing, case folding, tokenizing, filtering, dan stemming

\subsubsection{Transformation}

Tahap transformation bertujuan merubah bentuk data yang telah dipilih untuk dilakukan proses klasifikasi pada data mining. Data yang digunakan pada proses klasifikasi harus berupa data numerik, sehingga perlu dilakukan tahap transformation. Data yang sudah diubah dilakukan seleksi fitur menggunakan TF-IDF. Seleksi fitur ini digunakan untuk menghitung bobot setiap kata yang telah diubah.

\subsubsection{Data Mining}

Tahap data mining merupakan proses pengklasifikasian menggunakan algoritma Artificial Neural Network dengan metode backpropagation. Proses klasifikasi terdiri dari 2 proses yaitu proses pelatihan dan proses pengujian.

\subsubsection{Interpretation/Evaluation}

Tahap ini untuk mengevaluasi hasil kinerja klasifikasi yang telah diperoleh dengan menghitung nilai accuracy, precision, dan recall.

\section{HASIL DAN PEMBAHASAN}

Penelitian ini menggunakan 290 variabel dari 1625 data dengan persentase $80 \%$ data latih dan 20\% data uji, yaitu 1300 data digunakan sebagai data latih dan 325 data digunakan sebagai data uji. Uji coba dilakukan menggunakan 1 hidden layer dengan jumlah node yang diujikan sebanyak 1 -10 node dengan parameter learning rate sebesar $0.01-0.05$. Hasil uji coba penelitian dapat dilihat pada tabel 3.

Tabel 3. Hasil Uji Coba Penelitian

\begin{tabular}{ccc}
\hline Jumlah Node & Learning Rate & Akurasi \\
\hline \multirow{3}{*}{1} & 0.01 & 0.8585 \\
& 0.02 & 0.8523 \\
& 0.03 & 0.8554 \\
0.04 & 0.8585 \\
0.05 & 0.8554 \\
\hline \multirow{2}{*}{2} & 0.01 & 0.88 \\
& 0.02 & 0.8738 \\
& 0.03 & 0.8708 \\
& 0.04 & 0.8523 \\
3 & 0.05 & 0.88 \\
& 0.01 & 0.8615 \\
& 0.02 & 0.8646 \\
& 0.03 & 0.8554 \\
& 0.04 & 0.8431 \\
& 0.05 & 0.8523 \\
\hline & 0.01 & 0.8646 \\
& 0.02 & 0.8677 \\
& 0.03 & 0.88 \\
& 0.04 & 0.8677 \\
& 0.05 & 0.8646 \\
\hline
\end{tabular}




\begin{tabular}{ccc} 
& 0.02 & 0.8677 \\
& 0.03 & 0.8585 \\
& 0.04 & 0.8585 \\
& 0.05 & 0.8646 \\
\hline \multirow{3}{*}{6} & 0.01 & 0.8615 \\
& 0.02 & 0.8585 \\
& 0.03 & 0.8585 \\
& 0.04 & 0.8769 \\
& 0.05 & 0.8769 \\
\hline & 0.01 & 0.8646 \\
& 0.02 & 0.8646 \\
& 0.03 & 0.8523 \\
& 0.04 & 0.8492 \\
& 0.05 & 0.8492 \\
\hline & 0.01 & 0.8615 \\
& 0.02 & 0.8585 \\
& 0.03 & 0.8462 \\
& 0.04 & 0.8708 \\
& 0.05 & 0.8708 \\
\hline & 0.01 & 0.8677 \\
& 0.02 & 0.8646 \\
& 0.03 & 0.8708 \\
& 0.04 & 0.88 \\
& 0.05 & 0.8769 \\
\hline & 0.01 & 0.8769 \\
& 0.02 & 0.8862 \\
& 0.03 & 0.8646 \\
& 0.04 & 0.8646 \\
& 0.05 & 0.8646 \\
& &
\end{tabular}

Hasil uji coba pada tabel 3 menunjukkan bahwa tingkat akurasi paling tinggi yaitu sebesar 0.8862 dengan jumlah node hidden layer sebanyak 10 node dan learning rate sebesar 0.02 . Berikut ini model arsitektur ANN yang dipilih pada penelitian ini.

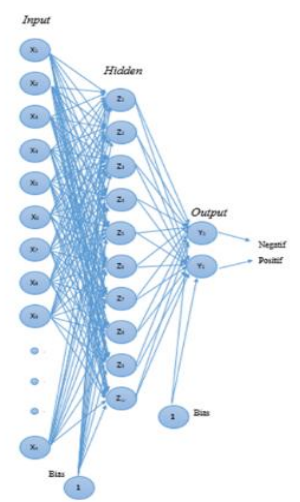

Gambar 6. Arsitektur Klasifikasi Penelitian

Hasil yang dipilih selanjutnya akan dilakukan evaluasi untuk mengukur kinerja klasifikasi yang telah dilakukan. Evaluasi dilakukan menggunakan confusion matrix. Berikut confusion matrix dari hasil klasifikasi ANN menggunakan 1 hidden layer yang berjumlah 10 node dan learning rate sebesar 0.02 dengan persentase $80 \%$ data latih dan $20 \%$ data uji.

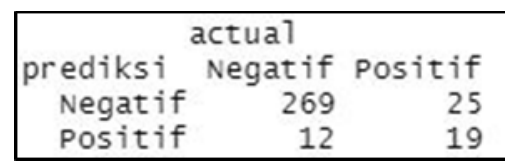

Gambar 7. Confusion Matrix Hasil Klasifikasi 
Berdasarkan gambar 7, algoritma ANN memprediksi dengan benar 269 data kelas negatif. Hasil tersebut menunjukkan bahwa ANN cukup baik untuk memprediksi sentimen negatif yang merupakan sentimen terbanyak pada dataset penelitian ini. Berikut perhitungan nilai accuracy, precision, dan recall secara manual dan menggunakan Rstudio.

$$
\begin{gathered}
\text { Accuracy }=\frac{T P+T N}{T P+T N+F P+F N}=\frac{19+269}{19+269+12+25}=\frac{288}{325} \times 100 \%=88,62 \% \\
\text { Precision }=\frac{T N}{T N+F N}=\frac{269}{269+25}=\frac{269}{294} \times 100 \%=91,5 \% \\
\text { Recall }=\frac{T N}{T N+F P}=\frac{269}{269+12}=\frac{269}{281} \times 100 \%=95,73 \%
\end{gathered}
$$

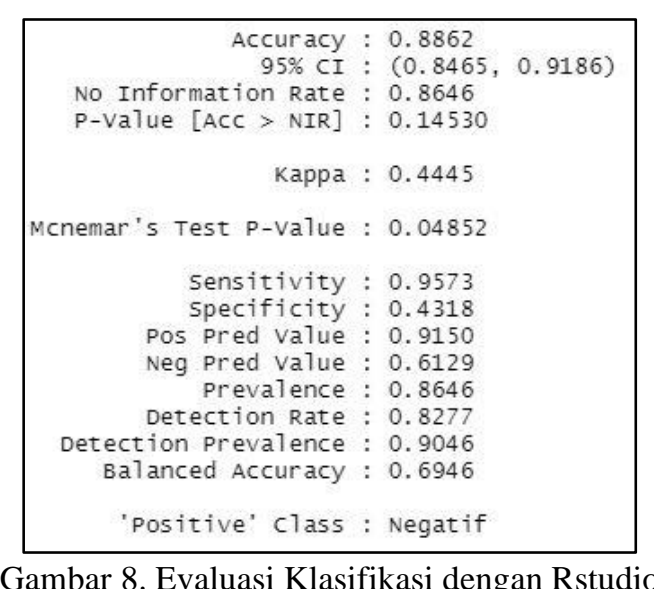

Berdasarkan hasil evaluasi menggunakan confusion matrix diperoleh nilai accuracy sebesar $88,62 \%$, precision sebesar 91,5\%, dan recall sebesar 95,73\%. Selain nilai accuracy dan precision, nilai recall yang dihasilkan juga cukup besar. Hal ini menunjukkan bahwa model klasifikasi yang dihasilkan masuk ke dalam kategori excellent classification, artinya klasifikasi yang dilakukan sebagian besar dapat mendeteksi dengan tepat [20].

\section{SIMPULAN}

Berdasarkan hasil penelitian yang telah dilakukan, dapat disimpulkan beberapa hal yakni sebagai berikut:

1. Klasifikasi opini publik terhadap Covid-19 menggunakan Artificial Neural Network (ANN) dilakukan beberapa tahap diantaranya dengan mengumpulkan data dalam bentuk teks terlebih dahulu, kemudian memilih data yang sesuai untuk digunakan dalam penelitian (selection). Selanjutnya melakukan tahap preprocessing menggunakan data yang telah diseleksi untuk membersihkan data yang digunakan. Tahap preprocessing terdiri dari 5 proses yaitu cleansing (menghilangkan karakter yang tidak berpengaruh), case folding (mengubah teks menjadi huruf kecil), tokenizing (mengubah kalimat menjadi kata per kata), filtering (penghapusan kata yang tidak berpengaruh), dan stemming (mengubah kata imbuhan menjadi kata dasar). Tahap selanjutnya yaitu transformation untuk memberikan bobot pada masing-masing kata. Tahap selanjutnya data mining dengan melakukan klasifikasi data teks menjadi sentimen positif dan negatif menggunakan ANN, namun data teks akan dibagi terlebih dahulu menjadi data latih dan data uji. Tahap terakhir yaitu melakukan evaluasi terhadap hasil klasifikasi dengan menghitung nilai accuracy, precion, dan recall dari confusion matrix hasil klasifikasi. 
2. Klasifikasi menggunakan ANN memperoleh hasil accuracy sebesar 88,62\%, precision 91,5\% dan recall 95,73\% dengan persentase 80:20 (80\% data latih dan 20\% data uji) dengan menggunakan 1 hidden layer yang berjumlah 10 node dan learning rate sebesar 0.02 . Pengetahuan yang didapatkan dari proses pengklasifikasian ini adalah penggunaan data dengan perbandingan jumlah node hidden layer dan jumlah learning rate mempengaruhi hasil accuracy, precision, dan recall dalam pengklasifikasian data sentimen menggunakan ANN.

\section{SARAN}

Beberapa hal yang disarankan dari penelitian ini untuk penelitian selanjutnya antara lain:

1. Perbanyak dataset dan atribut yang lebih berpengaruh untuk klasifikasi analisis sentimen agar tingkat akurasi yang didapatkan semakin meningkat.

2. Penelitian selanjutnya dapat menggunakan beberapa skenario pengujian untuk memperoleh hasil yang lebih baik.

3. Penelitian selanjutnya dapat menggunakan dataset dari bahasa lain selain bahasa indonesia.

\section{DAFTAR PUSTAKA}

[1] World Health Organization, "Novel Coronavirus (2019-nCoV): Situation Report-3," 2020. [Online]. Available: https://apps.who.int/iris/handle/10665/330762.

[2] Satuan Gugus Tugas Penanganan Covid-19, "Homepage Gugus Tugas Percepatan Penanganan Covid-19,” 2020. [Online]. Available: https://covid19.go.id/. [diakses 2 Februari 2021]

[3] Satuan Gugus Tugas Penanganan Covid-19, “Analisis Data Covid-19 Indonesia Update Per 07 Februari 2021,” 2021. [Online]. Available: https://covid19.go.id/p/berita/analisis-data-covid 19-indonesia-update-7-februari-2021.

[4] Muthia, D. A., Putri, D. A., Rachmi, H., \& Surniandari, A, "Implementation of Text Mining in Predicting Consumer Interest on Digital Camera Products," The 6th International Conference on Cyber and IT Service Management (CITSM 2018), pp. 1-7, 2018.

[5] Sopian, A., Wiyatno, A., \& Ryandi, A, "Komparasi Algoritma Support Vector Machine Dengan Algoritma Artificial Neural Network Untuk Memprediksi Nilai Persetujuan Kredit Modal Kerja yang diberikan Bank Umum," Jurnal Teknologi Informatika \& Komputer, vol. 5, no. 1, pp. 88-95, 2019.

[6] Ardika, R. B. P., Irawan, B., \& Setianingsih, C, “Analisis Sentimen Data Pada BPJS Kesehatan Dengan Metode Backpropagation Neural Network," e-Proceeding of Engineering, 2020, pp. 2-8.

[7] Rohmawan, E. P, "Prediksi Kelulusan Mahasiswa Tepat Waktu Menggunakan Metode Desicion Tree dan Artificial Neural Network," Jurnal Ilmiah MATRIK, vol. 20, no. 1, pp. 21 30, 2018.

[8] Rozi, I. F., Pramitarini, Y., \& Puspitasari, N, “Analisis Mengenai Calon Presiden Indonesia 2019 di Twitter Menggunakan Metode Backpropagation," Jurnal Informatika Polinema (JIP), vol. 6, no. 2, pp. 27-31, 2020.

[9] Mardi, Y, "Data Mining : Klasifikasi Menggunakan Algoritma C4.5," Jurnal Edik Informatika, vol. 2, no. 2, pp. 213-219, 2016.

[10] Noviando, E. S., Ervianto, E., \& Yasri, I, "Studi Penerapan ANN (Artificial Neural Network) Untuk Menghilangkan Harmonisa Pada Gedung Pusat Komputer,” Jom FTEKNIK, vol. 3, no. 2, pp. 1-6, 2016.

[11] Assuja, M. A., \& Saniati, S, “Analisis Sentimen Tweet Menggunakan Backpropagation Neural Network," Jurnal TEKNOINFO, vol. 10, no. 2, pp. 23-28, 2016.

[12] Solikhun., Safii, M., Trisno, A, "Jaringan Saraf Tiruan Untuk Memprediksi Tingkat Pemahaman Siswa Terhadap Mata Pelajaran Dengan Menggunakan Algoritma 
Backpropagation,” Jurnal Sains Komputer \& Informatika (J-SAKTI), vol. 1, no. 1, pp. 24-36, 2017.

[13] Rahayu, D., Wihandika, R. C., \& Perdana, R. S, "Implementasi Metode Backpropagation Untuk Klasifikasi Kenaikan Harga Minyak Kelapa Sawit," Jurnal Pengembangan Teknologi Informasi dan Ilmu Komputer, vol. 2, no. 4, pp. 1547-1552, 2018.

[14] Achmalia, A. F, "Peramalan Penjualan Semen Menggunakan Backpropagation Neural Network dan Recurrent Neural Network (Studi Kasus di PT Semen Indonesia (Persero) Tbk)," 2019.

[15] Luqyana, W. A., Cholissodin, I., \& Perdana, R. S, "Analisis Sentimen Cyberbullying pada Komentar Instagram dengan Metode Klasifikasi Support Vector Machine," Jurnal Pengembangan Teknologi Informasi dan Ilmu Komputer, vol. 2, no. 11, pp. 4704-4713, 2018.

[16] Fibrianda, M. F., \& Bhawiyuga, A, "Analisis Perbandingan Akurasi Deteksi Serangan Pada Jaringan Komputer Dengan Metode Naive Bayes Dan Support Vector Machine (SVM)," Jurnal Pengembangan Teknologi Informasi dan Ilmu Komputer, vol. 2, no. 9, pp. 3112-3123, 2018.

[17] Zannah, R, "Analisis Sentimen Pada Media Sosial Twitter untuk Klasifikasi Opini Islam Radikal Menggunakan Jaringan Saraf Tiruan,” 2019.

[18] Anggreini, N. L, "Teknik Clustering Dengan Algoritma K-Medoids untuk Menangani Strategi Promosi di Politeknik TEDC Bandung," Jurnal Teknologi Informasi dan Pendidikan (JTIP), vol. 12, no. 2, pp. 1-7, 2019.

[19] Handani, S. W., Saputra, D. I. S., Hasirun, Arino, R. M., \& Ramadhan, G. F. A, "Sentiment Analysis for Go-Jek on Google Play Store," Journal of Physics: Conferences Series, pp. 1-6, 2019.

[20] Palit, F. K. E., \& Sulistyo, W, “Analisis Accuracy, Specificity, dan Sensitivity Artificial Neural Network Pada Fitur Time Based Traffic,” 2017. 